\title{
The Response of Stock Prices to Changes in Weekly Money and the Discount Rate
}

\author{
R. W. Hafer
}

A. Wher is a research officer at the Federal Reserve Bank of St Louls. The author would like to thank Stu Allen, Gikas Hardouvelis, Scott Hein, Jan Loeys, Doug Pearce, Jim Schmidt and Jim VanderHoff for their suggestions and comments on earlier drafts of this paper. Thomas A. Polmann provided research assistance.

The surveys by Cornell (1983) and Sheehan (1985) contain numerous references to the literature on this subject.

Alternative evidence is presented in Hein (1985), and Falk and Orazem (1985).

apearce and Roley $(1983,1985)$ find that stock prices react only to unanticipated changes in money and, for the most part, show no statistical relationship to either unanticipated or expected movements of other economic news. Hardouvelss (1985) reports that stock prices react to unanticipated movements in four monetary measures ( $M 1$, net free reserves, the discount rate and the discourt rate surcharge), as well as three non-monetary measures (trade deficit, unemployment rate and personal income). Although few studies have examined the weekly money/stock-price relationship, numerous studies have studied the longer-term reaction of stock prices to movements in money. Among others. see Sprinkel (1964). Rozeff (1974). Sorensen (1982) and Davidson and Froven (1982).

Various studies also have examined the behavior of stock prices to announcements of different types of information. For example, Schwert (1981) examines the reaction of stock prices to the announcement of inflation data: Fama. et. at (1969) study the effects of stock splits; Lloyd-Davies and Canes (1978) investigate the effects of stock analysis' publisted recommendations; and Niederhofter (1971) analyses the reaction of stock prices to "world events."

This paper extends previous reseanch on the reaction of stock pices to monetary "news" in several ways. First, it covers a broader time period, from September 1977 through December 1984, than most previous studies. This allows one to test whether the changes in monetary policy operating procedures in October $197^{9}$ and Octobes 1982 influenced the response of stock prices to changes in the money stock and the discount rate.

Second unlike previous studies, this study uses both broad and industry-specitic measures of stock prices to detemine if general market effects also occur uniformily across in specific industry groups. As noted by King (1966):

". . is is intulinely appealing to think of incoming information as lalling ing varous classes acconthing to the scope of its effect on the manket. Theme is some news of a monetary nature, for example, which is bourd to have a manke-wide impact on secunty price. the magnitude of inpact need not, howeror, be the same fol all stocks." 140

Athough numerous studies have attempted to determine optimat groupings of indivitual stocks based on their relative movements over time, little has been done to investigate the relative response of different stock groups to the same piece of economic: information.

A discussion of the October 1982 change in poltcy procedures can be found in Wallich (1984) and Gilber: (1985).

5 Most previous research focuses solely on the broad market effects. For example, Pearce and Roley (1983) use the Dow Jones industrial Average while Pearce and Roley (1985) use the Standard and Poor's 500 index. In an approach similar to that used in this study, Hardouvelis examines the effect of new information on several different stock price measures. 
Finally, unlike most prevous work, which presumed that the reaction of stock prices was symmet ic with respect to unanticipated increases or deceases in money, this paper lests for the separate effect of positve and negative unexpected changes in M1. This

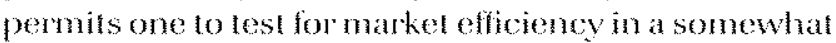
differen manner than simply lesting for the significance of expected and unoxpected changes in money:"

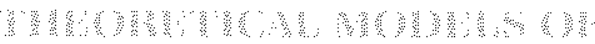

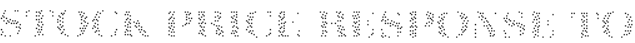

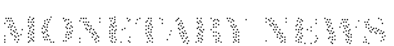

The afficient makets hypothesis suggests that, when expected changes in the money stock occur they hate no significant effect on stock prees because they already have been ineoporaled into secully pricess. Only thexpected changes in the money sock affect stock prices according to this hypothesis.

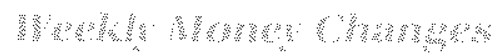

Several hypotheses have been suggested to explain why stock prices react to unexpected changes in the money stock." The expected hilation hyothess suggests that an unexpected increase in the money stock increases market parlicipants expectations of inflation, leading lo higher interest mates via the somatled Fisher effect. If the increase in hoterest rates lowes the present value of conporations' discomonted cash thows, stock prices will lall whenever investots obsere an umexpected increase in the money stock. This hvoth esized lesponse does not oceur, however, Lnder cen tain restrictive conditions. Given perfect makets and no taxes, for example, changes in expected inflation would have no effect on stock prices, becatse expected increases in nominal cash flows would offset

ECornell, Pearce and Roley (1985) and Hardouvelis provide no evidence on this issue as it relates to stock price effects. Pearce and Roley (1983) present evidence on the response of stock prices when money deviates from announced long-run target ranges. Their tests are based on separating unanticipated money into positive surprises above targe?, negative surprises below target and all others. In general, their results indicate that the different surprise measures are not statistically different in their effect. There is, however, some evidence of a different effect of positive surprises across the different policy regimes.

'As Sheehan (1985) notes, the unexpected change in the money stock provides new information about money stock developments that already have occurred. That is because the money stock is announced with a lag. Thus, the announcement causes market participants to revise their forecasts for future policy actions apart from previously held expectations only if the announced money stock change is different from its expected change.

${ }^{8}$ This discussion is based on Comell and Sheehan. the effect of inceases in the rate at which those flows are discounted ${ }^{*}$ A large litemature addresses these conditions, showing that they generally are not fulfilled. Based on these studies, which indicate that stock prices react negatively to intlation, the expected inflation hypothes is suggests that stock prices should fall following the announcement of an unexpected increase in the money stock.

An altemative hypollosis, the policy anticipaloms hypothesis, views an moxpected change in the mothey stock at a signal that altes market pereptions of future monetary polioy. Presuming that the change is pereved as permatnent or that he frederal Resere is slow to respond to unexpected deviations in the money stock away forn its laget lewel. interest lates will rise as the public expects the fee to offsed the unexpected increase in the money stock. Consequenty, an unexpected inerease in the money stock implies greater future tighening of credit avalabiliv, which results in highes interest tates. Bexaluse hat higher interest bates reduce the present valte of dis counted cash flows, stock prices are hypothesized to decline.

Finaly, the monev demand of real activity hyothe: sis asserts that money annoumcenents provide information about future money demand. Suppose that market participants interpet an unexpected increase in the noney stock as a signal that there has been a permanent increase in money demand. If monev demand depends on expected future output, then the unexpected increase in money demand indicates that future output will be higher than previously expected "Consequently, the increase in expected cash

\footnotetext{
This discussion abstracts from the distinction of net monetary creditors and net monetary debtors. For a discussion of the effects of changes in inflation expectations on each group, see Kessel and Alchian (1962). For a more recent study of the effects of inftation on bank stock prices, used to represent a group of net monetary creditors, see Santoni (1986).

For example, Feldstein (1980) discusses the effect of taxes Schwert (1981), Fama and Schwert (1977) and Netsol (1976) examine the intation-stock price relationship for the United States white Branch (1974) and Cohn and Lessard (1981) provide evi dence from other countries. An general, these studies indicate that unexpected increases in inflation lower stock prices. Results reported in Kool and Hater (1986), however, suggest that this result does not hold for earlier time periods.

fiFama (1981) argues that expected inflation in previous studies serves as a proxy for expected real activity. Consequently, regress ing stock prices of expected inflation without accounting for expected reas activity will yield incorrect estimates. Following this line of reasoning, several researchers have used available survey data to study the retationstip between expected stock price changes, expected inflation and expected real activity. See. for example, Gultekin (1983), Pearce (1984), Hasbrouck (1984) and Coate and VanderHoff (1985).
} 
flows produces an increase in stock prices. This hym pothesis thus predicts that stock prices should increase in response to an unexpected increase in the money stock.

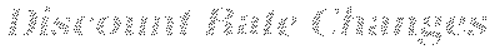

Discount rate changes may be bought of as an indication of changes in expected future monetary policy; discount rate changes, in other wouds, affect financial and stock markets primaty through thei effect on interest rates and perceptions of luture economic activily ${ }^{\text {t. }}$ In general, incleases in the discount rate reduce stock prices because they presage a tightening of monetary policy. ${ }^{1+}$ "The nove toward tighter policy is expected to increase interest rates and reduce real economic activity and, consequently, fulure corporate cash flows. Stock prices decline because the reduced future cash flows are discounted at higher interest lates.

Some argue that the impact of a discomn rate change clepends on the federal Reserve's curant opelating procedure ${ }^{\text {* }}$.f the fed is targeting interest rates, changes in the discount rate may provicle no information about future policy that is not already

talt shoutd be noted that attendant increases in the ex anfe real rate are presumably more than of set by expected increases in future real econoric activity.

Batten and Thom mon (1985) and Smirlock and Yawiz (1985). for example, each attempt to determine "technical" from "nontechnical" changes in the discount tate. Batten and Thonton dichotomize discount rate changes into technical or policy-related, based on Federal Reserve statements. Their procedure assumes that the change is entirely technical or policy-related.

Smiflock and Yawitz attempt to define technical and non-technical discount rate changes by regressing rate changes on lagged values of the spread between the federal funds rate and the discount rate and lagged values of changes in discount window borrowing. Predicted values from this equation constitute the fechnical (or anticin pated change, while the regression's errof term constitutes the non-technical (or unanticipated) change in the discount rate.

Several factors militate against this procedure. First, if does not capture effects not incorporated in the explanatory variables. Second, it may alter the timing of the actual change. Last it assigns each discount rate change, which generally is 25,50 or 100 basis points, some estimated value that often does not equal the actual value. In other words, there is always some non-tectnical change.

Because of the problems surrounding these classifications of discount rate changes, we take the changes to be unanticipated.

"There are instances, however, when moves to raise the discount rate have been received by the market as good news precioitating increases in stock prices. This is discussed in the shaded box on the next page.

1: For example, see Roley and Troll (1984) or Smirlock and Yawitz for a discussion of this point. incorporated in inferest mates. If the fed is using a reserve growth operating procedure, however, changes in the discount rate inthence interest ates. During the period covered by this study, three different opelating procedures were used: interest mate targeting (pre-October 1979); nonborrowed reserves talgeting loctobea 1979 to october 1982); and a borowed reserves procedure, which tends to smooth nowem ments in the funds rate more than nonborlowed reserves targeting (post-October 1982). The empirical tests below assess the different effects of discount wate changes under different policy procedures.

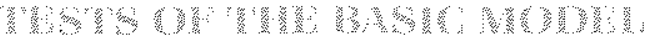

The basic equation tested is:

(1) $\Delta \mathrm{SP}_{\mathrm{a}}=\alpha_{2}+\beta_{1} \mathrm{UM}_{4}+\beta_{2} \mathrm{HM}_{1}+\beta_{2} \mathrm{OR}_{1}+\beta_{1} \mathrm{OHS}_{1}+\varepsilon_{1}$

where:

$\Delta \mathrm{SP}=$ the fist-diference of the logation of the daily stock price index.

UM = the unexpected dollar change in ML.

$\mathrm{EM}=$ the expected change in M1,

DR $=$ the change in the discount rate, and

Dhs = the change in the discount rate surchange."

The efficient matkets hypothesis suggests that the estimated coetficienl on expected money changes $1 \beta_{2}$; should be zero. If discount rate changes influence stock prices as hypothesized above, $\beta_{\text {: }}$ and $\beta_{4}$ will be negative. Finally, the expected sign of $\beta$, difers depending upon the hypothesis being tested. The policy anticipations and the expected intlation hypotheses siggest that it will be negative; the money clemand hypothests suggests that it will be posilive

Besides imestigating the vatidily of several hypotheses regarding the effects of monev stoek and tiscount falle changes on stock prices, estinates of equation 1 can be used to test several other livpolheses as woll: Are the effects of the explanatory variables statis ifally equal across elfferent monetay policy megimes? Me the effects simila acoss slock price indexes? Are llow effects of noney slock changes on slock prices symmetrical as gonerally is assumed?

\footnotetext{
The discount rate surcharge was used by the Federal Reserve during the period from March to May 1980 and again during the period from November 1980 to November 1981. The 1980 imposition of the surcharge was part of the credit restraint program enacted by the Carter administration and it was set at 3 percent. Durng each period when the surcharge was used, it applied to discount window borrowings by banks with deposits of $\$ 500$ million or more that borrow frequently. Because the surcharge did not apply to all borrowing, it is included as a separate variable in the regression equations presented below.
} 


\section{Timing Discount Rate Changes}

Studies using discount rate changes often take the amnouncement date as the day it becomes public How one times the publication of the new information, however may alter the empirical results For example there are occasions on which discount rate changes ate announced doming the fading day and, as such, the actual announcement day will differ from the day it is reported by the financial press because of this, we enter the discotnt rate change on the trading day that the change becones effective.

To lliustrate how sensitive the results are to changes in the timing the sP500 equation was re estimated for the pre october 1979 period defining the announcement date as that day when the dis. eount rate change appeared in the the wall street Jowmal An exammation of the data revealed that, on Friday, November 1,1978 , the discount nate was ansed 100 basis pomts durng the trading day $\mathrm{Ac}$ counts in the Wall stree foumal on Monday attrib we the steck price rally on F tav to the announce-

To assess these questions, equation 1 was estimaled using daily stock price data from September 23,1977 . hlwough December 31, 1584, "Thee zeno-one dumny varables were used to differentiate lhe periods associated with al temative monetary policy regimes. Thlus, $01=1$ from Septenther 23, 1975, Anough Oelotor 5 , 1979, zero elsewhere; $02=1$ from October 5,1979 . theugh oetobes 15,1982 , zero elsewhere; and bs $=1$ after October 15, 1982, zero elsewhere. Interaction terms are formed by mulliplving ach explanatory variable by these demmy varables." Hor examples D1LM represents the oflect of UM in the fust subpefiot, D2UM the effect duing tho second and so on. Table 1 presents the Jesults of estinating equation 1 asing these inteatction terms and the varous slock price indexes."

${ }^{17}$ Because the discount rate surcharge variable enters only during the second subsample, no interaction term is necessary. Also, the choice of October 15 for the 1982 policy change is arbitrary, since published accounts of the procedural change do not provide an exact date

1aNote that equation 1 is estimated without day-of-the-week variables. Previous analysis by Pearce and Roley (1985) using the same data finds that the presence or absence of these variables did not influence their resuts. Given this evidence and the fact that we are using the same data, we also omit day-of-the-week vatiables. Other evidence on the existence of day-ot-the-week effects, much of it ment suggesting that the increase in the drscount rate reaffrmed the market perception that the red was resolved to rein in money growth and 10 reduce the possibility of future inflation lf we change only this one annowncement date from the day it be came effective (Friday) to the day it appeared in the Wall Street Joumal (Monday) the estimated relationship becomes

$$
\begin{aligned}
& \triangle S P 500=004-0098 \mathrm{UM}_{1}-0872 \mathrm{DR}_{2} \\
& \text { (1.14) (2,18) } \quad \text { (205) } \\
& \mathrm{R}^{2}=0015 \mathrm{SE}-0713 \mathrm{OW}-168
\end{aligned}
$$

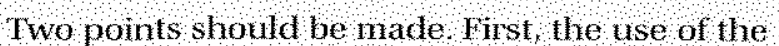
effective ady is theoretically preferable to dathg the annowneement by its appearanee in the financal pless second, the empmical effects of discount rate changes on stoel prees appear to be quite sensitive to small timing ohanges In this example, changing one observation reverses the $5 i g n$ and significanee of the discontit rate vantable.

As the effichen makes hvpothesis predicts. the expected change in wa low does not signilically affect stock price ehanges. The results in lathe 1 indicale that none of the 15 estimated coetficients on expected money is statistically significanl at the 5 percon level of significance. The test results in table? also bear out the officient makets hypolnesis, as tho reported f-statistics cannot reject the hypothesis that the coefficients on the expecied change in monev together are insignifindly different from zero. Thus, the hypothesis that the estimated coethients on expected money ale zero across the different monelary regimes is not rejected by the data.

As predicted by the expected inflation and policy anticipations hypotheses, but counter to the money

conflicting, are reported in French (1980) and Gibbons and Hess (1981).

Following Pearce and Roley (1985) and Hardouvelis, we also included several other measures of economic "news" as explanatory variables in equation 1 . Those results indicated that stock prices, irrespective of the index, responded to monetary announcements more reliably than the other measures, such as unexpected inflation, economic activily or unemployment. Because the results of these tests do not extend the analysis atready provided by Pearce and Roley, we do not report them here. 
Table 1

Estimates of Equation 1

\begin{tabular}{|c|c|c|c|c|c|}
\hline \multirow[b]{2}{*}{ Variable } & \multicolumn{5}{|c|}{ ndex } \\
\hline & SP500 & SP4OO & SPTHAN & SPUTL & SPFIN \\
\hline Constant & $\begin{array}{l}0025 \\
1201\end{array}$ & $\begin{array}{l}0025 \\
(114)\end{array}$ & $\frac{0,027}{(0,98)}$ & $\begin{array}{l}0.012 \\
(0,86)\end{array}$ & 0018 \\
\hline OUUM & 0,000 & 10104 & $\begin{array}{l}0164 \\
(229)\end{array}$ & $\begin{array}{l}0037 \\
(102)\end{array}$ & $\begin{array}{l}0.060 \\
(1.03)\end{array}$ \\
\hline DeUM & $\begin{array}{r}0,24 \\
(3,84)\end{array}$ & $(3.58)$ & $\begin{array}{r}0.067 \\
(1,60)\end{array}$ & $\begin{array}{l}0129 \\
(6.05)\end{array}$ & $\begin{array}{l}0.149 \\
(437)\end{array}$ \\
\hline ooum & $\begin{array}{l}0112 \\
(246)\end{array}$ & $=0.47$ & $\begin{array}{l}0.091 \\
(154)\end{array}$ & $\begin{array}{l}049 \\
(396)\end{array}$ & $\begin{array}{l}0 \\
(260)\end{array}$ \\
\hline OUM & $\begin{array}{l}0072 \\
(1,4)\end{array}$ & 0.077 & $(0,29)$ & 0.036 & (0)503 \\
\hline B2EM & 00072 & 9073 & 0.01 & 0.048 & $\begin{array}{l}0.031 \\
(0.56)\end{array}$ \\
\hline 63an & $(0,074$ & 0.037 & $\begin{array}{r}0021 \\
(0,34)\end{array}$ & $\begin{array}{l}0,022 \\
(072)\end{array}$ & 009 \\
\hline of? & $\frac{090}{(77)}$ & 1008 & $\begin{array}{l}1,89 \\
176)\end{array}$ & $\begin{array}{l}0.259 \\
(076)\end{array}$ & $(0,942$ \\
\hline D2DP & 0,0597 & (2) 2,279 & (0, & 0282 & 9048 \\
\hline DSBA & 1254 & (1, 1515 & 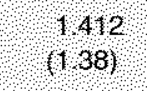 & $(0,5269)$ & $\begin{array}{l}0,336 \\
0,41\end{array}$ \\
\hline ORS & $\begin{array}{l}0,432 \\
(266)\end{array}$ & $\begin{array}{r}0421 \\
(248)\end{array}$ & (4) & $(508)$ & 0.658 \\
\hline $\mathrm{B}^{2}$ & 0,020 & 0.018 & 0009 & 0009 & 0021 \\
\hline$S E$ & 0887 & 0993 & 9165 & 0596 & 0952 \\
\hline ow & 170 & 182 & 200 & 398 & 201 \\
\hline 1 & & 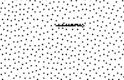 & $\begin{array}{l}0.19 \\
8.31)\end{array}$ & $(1,36)$ & $\begin{array}{l}0.23 \\
(9.88)\end{array}$ \\
\hline
\end{tabular}

NOTE Absolute value of (statistics are reported th parentheses. Rे is the coefficient of determination adusted tor degrees of freedorn SE is the regression standard errot, BW is the Durbih Watson test statistic and of the estumate of the first-order serial correlation coefticient The dependent variables are heasured as first differences of the logaithms of Standard and Poor s 500 (SP 500 , 400 slock index SP 400 the transportation index (SPTRAN) the uidty hedex (SPUTIL) and the financial hdex (SPFIN) The tight hand side neasures are unexpected changes (UM) and expected changes h M (IEM) based on the Money Market Servees. Inc survey, DH and DHS reptesent the percentage otange in the Federal Heserves discoun rate and surcharge rate, respectively the terms DI 02 and D3 represent (0, 1$)$ dumny variables where Dt 1 rom Septenber 23,1977 hrough october $5,1979,0$ elsewhere: b2 4 from october 5,1979 , through Oetober $15,1082,0$ elsewhere, and D3 1 from October 15 982, 10 December 31,1984 0 elsewhere.

demand hypothesis, unanticipated changes in M1 (UM) generally have a statistically significant, negative impact on stock prices. For instance, an unanticipated $\$ 1$ billion increase in $\mathrm{MI}$ reduced the growth rate of the SP500 and the SP400 by about 10,12 and 11 basis points across the three periods tested. The results in table 2 provide supporting evidence that unantici- pated money stock changes do affect stock prices. The results on line 3 reject the claim that unanticipated changes in M1 have no effect; the resuls on line 4, which test the equality of the estimated coefficients across the different policy periods, indicate that one cannot reject coefficient stability at the 5 percent level. These results show that only unexpected changes in 
Table 2

\section{Hypothesis Test Results}

\begin{tabular}{|c|c|c|c|c|c|}
\hline \multirow[b]{2}{*}{ Hypothesis } & \multicolumn{5}{|c|}{ Index/rstatistics } \\
\hline & SP500 & SP400 & SPTRAN & SPUTL & SPFIN \\
\hline $\mathrm{DIEM}=\mathrm{D} 2 \mathrm{EM}-\mathrm{DSEM}-0$ & $(030)$ & 124 & $(0,26)$ & $1036)$ & $10.24)$ \\
\hline $\mathrm{D} 1 E M=\mathrm{D} 2 \mathrm{EM}=\mathrm{D} 3 E \mathrm{M}$ & 0,9 & 0084 & $\begin{array}{l}120 \\
(0.30)\end{array}$ & 016 & 0.46 \\
\hline DIUM $=$ D $U$ UM $=\mathrm{D} 3 \mathrm{UM}=0$ & 804 & $(000)$ & $\begin{array}{l}340 \\
(002)\end{array}$ & 1781 & 8.96 \\
\hline DUUM - DLUM $=$ DSUM & 008 & 003 & 068 & 248 & 0,88 \\
\hline $\mathrm{D} 1 \mathrm{DA}=\mathrm{D} 2 \mathrm{OR}=\mathrm{D} 3 \mathrm{DA}=\mathrm{o}$ & (0,66) & 381 & 200 & 1029 & $(0,11)$ \\
\hline DTDR $=\mathrm{D} 2 \mathrm{OA}=\mathrm{QBOA}$ & 515 & $(0,4)$ & 297 & $1036)$ & $\begin{array}{l}278 \\
(0.06)\end{array}$ \\
\hline
\end{tabular}

NOTE Marghal significance levels are reported n parentheses, Variable definitions are found in table?.

money reliably influence the behavior of stock prices and that there appears to be no statistically significant change in this response across the different monetary policy regimes.".

The general hypothesis about discount rate changes on stock prices does not fare so well as the hypothesis about the effects of unanticipated changes in M1. Discount rate changes generally had a positive but not statistically significant 15 percent level effect on stock prices before October 1979 and after October 1982. This result does not support the view that discount rate inceases should negatively influence stock prices. It does, however, support the notion that, during periods in which monetary policy emphasises the behavior of the federal funds rate, the discount rate may not impart relevant policy information not already contained in, for example, the federal funds rate.

The results for the October 1979 to October 1982 period indicate that changes in the discount rate result in stock price movements genemaly consistent with the hypothesis described above. Changes in the discount rate have a significant cone-tailed negative

\footnotetext{
${ }^{19}$ This evidence is in sharp contrast to the results from studies examining the interest-rate/money relationship over this period.

avlt should be noted that the discount rate changes during the preOctober 1979 period are positive and significant at the 10 percent level for all of the indexes except SPUTl.. For a possible explanation of this resul, see the shaded insert on page 8 .
}

effect on atl indexes during this period, except for the SPTRAN index. The size of the estimated coeficients, however, is lower for the more narrowly defined indexes than it is for the broad SP500 and SP400 measures. Thus, a 100 basis-point increase in the discount rate during this peliod led to a 60 basis-point dedine in the growth rate of SP500 and SP400, but only a 28 basis-point drop in the growth rate of the spurIL. index.

Why are the effects of discount rate changes so different across the different policy regimes? Prior to October 1979, movements in the federal funds rate directly conveyed information about changes in policy objectives, thus making the informational content of discount rate changes redundant ${ }^{3}$ A similar argument can be made about the post-October 1982 period, since the switch from a nonborrowed to a borrowed reserves targeting procedure is similar to a policy that smooths movements in the federal funds rate. ${ }^{22}$ The finding that the estimated coefficients on

\footnotetext{
2:The evidence in the shaded insert on page 8 and accounts of discount rate changes in the Wall Streef Journal do not support the gross generality of this view.

2af a borrowings target (referred to as the borrowings assumption) is used and the primary deteminant of discount window botrowing is the federal-funds-rate/discount-rate spread, increases in the funds rate. ceteris paribus, necessitate an increase in reserves since borrowings will otherwise increase. Thus, reserves are injected, the funds rate falls and borrowings return to their desired level. This policy scerario suggests that movements of the federal funds rate after October 1982 again directly reflect policy objectives. For a more complete discussion, see Gibert.
} 
discount rate changes are insignificantly different from zero during the two different policy regimes suggests that the market's perception of changes in the discount rate may not be any different after October 1982 than it was before October 1979.

The test results in table 2 indicate that the discount rate change is an important variable in explaining the behavior of the broad indexes, but is less so for the more specialized groups. In fact, the reported $F$ statistic for the SPUTL index indicates that we cannot reject the hypothesis that changes in the discount rate together have no significant effect. The test results also reveal that the effect of discount rate changes is not equal across regimes at reasonable levels of significance (except for SPUTLL).

Finaly, the estimated coefficient on the discount rate surcharge (DRS) is highly significant and negative for each of the stock price indexes tested. The magnitude of the effect on the broad stock price measures is similar to that found by Pearce and Roley (1985); in addition, all of the stock price measumes are affected. In fact, unlike the results for the discount rate, which tend to have a smaller effect on the narrower indexes, a change in the surcharge rate actually had a larger impact on the narrow indexes.

To summarize, the hypothesis that only unanticipated changes in money negatively influence the movement of stock prices cannot be rejected. This finding, which holds for most of the stock price indexes used and time periods tested, supports the efficient makkets hypothesis, rejects the money demand hypothesis and corroborates earlier results based solely on the use of broad stock price indexes. It also shows that the effect of discount rate changes varies among the particular indexes and over the periods tested. Thus, although policy regime changes do not appear to influence the market's reaction to unanticipated changes in money, the evidence suggests that the information conveyed through discount rate changes varies across policy regimes.

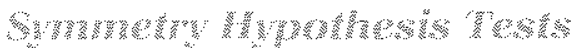

Analysts generally assume that positive and negative unanticipated changes in money have symmetrial influences on stock prices. To test this hypothe-

2Little research into the symmetry of the effects is available. Although Pearce and Roley (1983) and Roley and Troll (1983) test for the effects on interest rates when noney changes are above of below stated policy largets, this does not directly address the hypothesis. Also, Pearce and Roley (1983) present similar lests for stock prices. sis, we again use zero-one dummy variables to generate the appropriate interaction terms that differentiate positive and negative observations of UM.

Table 3 presents the results of this test. Positive values of UM are denoted by UM $(+)$; negative values by UM $(-1)^{2+}$ Negative unexpected changes in money have no statistically significant effect on stock prices using the SP500, SP400 and the SPTRAN indexes. In each case, the reported t-values are quite small, as are the estimated coefficients. In tests of the equality of the coefficients on the positive and negative values of UM, we find that, for these three stock price measures, the $t$-statistics are large enough to reject equality at the 5 percent level. It appears that only positive values of UM have significant effects on changes in these stock prices; the growth rates of these indexes fell by 16 basis points for a $\$ 1$ billion surptise in $M 1$. This result suggests that market efficiency is violated.:

The SPUTIL and SPFIN results indicate that both positive and negative values of UM have similar, statistically significant effects on the stoek price changes. In these instances, the calculated t-statistics to test coefficient equality afe well below any acceptable level of significance. The symmetrical response of utility and financial stocks to an unanticipated increase or decrease in the money stock indicates that these stocks are relatively more sensitive to interest rate and price level movements than other stocks.

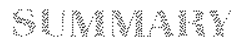

The results of this study generally support the efficient markets hypothesis. Based on ovidence from several different stock price indexes, unanticipated changes in money have a slatistically significant effect on stock prices. Expected changes in money never display a statistically significant effect. The estimated effect of unanticipated changes in money did not differ across altemative monetary policy regimes. One

\footnotetext{
2Aalues of zero are included in the UM $(+)$ data. Discount rate variables are omitted from the SPUTIL equation, becalse the evidence in table 2 indicates that they are not significant (jointly) at any reasonable level. It should be noted that reestimation of the equations in table 3 using a seemingly unrelated regression procedure does not alter the conciusions reached in this section.

${ }^{25}$ Gikas Hardouvels, in private correspondence, suggests the following scenario. Consider the median lorecaster facing the money armouncement with equal probability that the announced $M$ f foure will be above or below the forecast. Given the results in table 3 , the strategy is to sell before the announcement, since a positive surprise in money will lower stock prices while a negative sutprise has no statistical effect. If such response persists, market efficiency is violated.
} 


\begin{tabular}{|c|c|c|c|c|c|}
\hline \multicolumn{6}{|c|}{ Table 3 Results for Symmetry Test } \\
\hline \multirow[b]{2}{*}{ Variable } & \multicolumn{5}{|c|}{ Index } \\
\hline & SP500 & SP 400 & SPTRAN & SPUTIL & SPFIN \\
\hline Constant & $\begin{array}{l}0.048 \\
(2,18)\end{array}$ & $\begin{array}{r}0049 \\
(216)\end{array}$ & $\begin{array}{l}0.067 \\
(190)\end{array}$ & $\begin{array}{l}0024 \\
(120)\end{array}$ & $\begin{array}{r}0040 \\
(132)\end{array}$ \\
\hline UM( +$)$ & $\begin{array}{r}0162 \\
(507)\end{array}$ & $\begin{array}{r}0164 \\
(493)\end{array}$ & $\begin{array}{l}0,66 \\
(4,01)\end{array}$ & $\begin{array}{l}0,120 \\
(575)\end{array}$ & $\begin{array}{r}0,53 \\
(4,56)\end{array}$ \\
\hline $\mathrm{UM}(-)$ & $\begin{array}{r}0046 \\
(124)\end{array}$ & $\begin{array}{r}0041 \\
(108)\end{array}$ & $\begin{array}{l}0006 \\
(0,3)\end{array}$ & $\begin{array}{r}0086 \\
(365)\end{array}$ & $\begin{array}{r}0072 \\
(189)\end{array}$ \\
\hline DLOA & $\begin{array}{r}0,937 \\
(1,81)\end{array}$ & $\begin{array}{l}1059 \\
(1,96)\end{array}$ & $\begin{array}{l}1,95 \\
(17)\end{array}$ & & $\begin{array}{r}0,955 \\
(174)\end{array}$ \\
\hline D208 & $\begin{array}{r}0604 \\
(239)\end{array}$ & $\begin{array}{l}0607 \\
(230)\end{array}$ & $\begin{array}{l}0340 \\
(103)\end{array}$ & & $\begin{array}{r}0,446 \\
(1,66)\end{array}$ \\
\hline D3DA & $\begin{array}{r}1232 \\
(157)\end{array}$ & $\begin{array}{r}1,341 \\
(1,64)\end{array}$ & $\begin{array}{r}1.432 \\
(1.40)\end{array}$ & & $\begin{array}{r}0,394 \\
(0,47)\end{array}$ \\
\hline $0 \mathrm{ps}$ & $\begin{array}{l}0403 \\
(249)\end{array}$ & $\begin{array}{l}039 \\
(232)\end{array}$ & $\begin{array}{r}0.467 \\
(221)\end{array}$ & $\begin{array}{r}0551 \\
(522)\end{array}$ & $\begin{array}{l}0.637 \\
3.71\end{array}$ \\
\hline$t$ & $248^{\circ}$ & $252^{*}$ & $275^{\circ}$ & 107 & 158 \\
\hline $\mathrm{B}^{2}$ & 0.022 & 0021 & 0015 & 0039 & 0025 \\
\hline$S E$ & 0876 & 0912 & 1164 & 0597 & 0.952 \\
\hline $\mathrm{DW}$ & 179 & 182 & 200 & 198 & 201 \\
\hline$\theta$ & - & $\div$ & $\begin{array}{l}0.19 \\
(8.38)\end{array}$ & $\begin{array}{r}0.27 \\
(1173)\end{array}$ & $\begin{array}{l}0.23 \\
(9.94)\end{array}$ \\
\hline
\end{tabular}

NOTE: The reported $t$-statistic is based on testing the hypothesis that $U M(+)=U M(-$ ) An asterisk denotes significance at 5 percent tevel. All other terms are defined in table 1 .

result that does not suppot the efliciont matkets hypothesis is the finding that the effects of unanticipated money changes are asvmmetric: only positive values of amanticipated changes in money appeat to have a significant impact on the $S p 500, S p 400$ and SPTRAN measures.

The effects of discount mate changes on stock prices valy with changes in monefary policy procedures; their influence also lessened as the slock price index became narower. In genemal, fiscount late changes have significant negative effects on stock prices only from October 1979 to Octoluer 1982, a period chanacterized by a monetary policy that focused on contuolling nonborrowed reserves. Before and after that period, discount rate changes convey litte addilional information aboul policy.

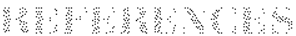

Batten, Dallas S., and Daniek L. Thomton. "The Discount Rate, Interest Rates and Foreign Exchange Rates: Ar Analysis with Daity Data," this Review (February 1985), pp. 22-30.

Branch, Ben. "Common Stock Performance and Inflation: An International Comparison," Joumal of Business (January 1974), pp. $48-52$.

Coate, D., and James Vandertoff. "Stock Returns, Intlation and Real Output," unpublished manuscript, Rutgers University (January 1985), forthcoming Economic Inquiry.

Cohn, Richard A., and Donaild A. Lessard. "The Effect of Inftation on Stock Prices: International Evidence," Journal of Finance (May 1981), pp. 277-89.

Comell, Bradford. "The Money Supply Amnouncements Puzzle: Review and Interpretation." American Economic Review (Septembet 1983) pp. 644-57.

Davidson, kawrence S., and Fichard T. Froyen. "Monetary Poltcy 
and Stock Returns: Are Stock Markets Efficient?" this Review (March 1982) pp. 3-12.

Falk, Barry, and Peter F. Orazem. "The Money Supply Announcements Puzzle: Comment," American Economic Review (June 1985), pp. 562-64.

Fama, Eugene F., Lawrence Fisher, Michael $C$. Jensen and Richard Roll. "The Adjustment of Stock Prices to New Information," international Economic Review (February 1969), pp. 1-21.

Fama, Eugene F., and G. William Schwert. "Asset Returns and Inflation," Journal of Financial Economics (November 1977), pp. $115-46$.

Fama, Eugene F. "Stock Returns, Real Activity, Inflation, and Money," American Economic Review (September 1981), pp. 54565.

Feldstein, Martin. "Inflation and the Stock Market," American Economic Review (December 1980), pp. 839-47.

French, Kenneth 月. "Stock Returns and the Weekend Etfect," Joumal of Financial Economics (March 1980), pp. 55-69.

Gibbons, Michael R., and Patrick Hess. "Day of the Week Effects and Asset Returns," tournal of Business (October 1981), pp. 57996.

Gilbert, A. Alton. "Operating Procedures for Conducting Monetary Policy," this Review (February 1985), pp. 13-21.

Gultekin, N. Bulent. "Stock Market Returns and Inflation Forecasts," Joumal of Finance (June 1983), pp. 663-73

Hardouvelis, Gikas A. "Macroeconomic Information and Stock Prices," unpublished manuscript, Columbla University (September 1985).

Hasbrouck, Joel, "Stock Returns, Inflation, and Economic Activity: The Survey Evidence," Joumal of Finance (December 1984), pp. 1293-310.

Hein, Scott $E$. "The Response of Short-Term Interest Rates to Weekly Money Announcements: Comment," Joumal of Money, Credit and Banking (May 1985), pp. 264-71.

Kessel, Reuben A., and Armen A. Alchian. "Effects of intlation," Joumal of Political Economy (December 1962), pp. 521-37.

King, Benjamin F. "Market and Industry Factors in Stock Price Behavior," Joumal of Business (January 1966), pp. 139-90.

Kool, Clemens J.M., and R. W. Hafer. "Intlation and Stock Prices: A Long Term View," Federal Reserve Bank of \$t. Louis Working Paper No. 86-001 (January 1986).

Lloyd-Davies. P., and Michael Canes. "Stock Prices and the Publi- cation of Second-Hand Intormation," Journal of Business (January 1978), pp. 43-56.

Niederhoffer, Victor. "The Analysis of World Events and Stock Prices," Journal of Business (April 1971), pp. 193-219.

Nelson, Charles R. "Inflation and Rates of Return on Common Stocks," Journal of Finance (May 1976), pp. 471-82.

Pearce, Douglas K. "An Empirical Analysis of Expected Stock Price Movements," Journal of Money, Credit and Banking (August 1984), pp. $317-27$.

Pearce, Douglas $K$, and V. Vance Rotey. "The Reaction of Stock Prices to Unanticipated Changes in Money: A Note." Joumal of Finance (September 1983), pp. 1323-33.

ness (January 1985), pp. 49-67.

Roley, V. Vance, and Rick Troll. "The Impact of New Economic Information on the Volatility of Short-Term interest Rates, "Federal Reserve Bank of Kansas City Economic Review (February 1983). pp. 3-15.

"The Impact of Discount Rate Changes on Market Interest Rates," Federal Reserve Bank of Kansas City Economic Review (January 1984), pp. 27-39.

Rozeff, M. S. "Money and Stock Prices: Mafket Efficiency and the Lag in Effect of Monetary Policy." Joumal of Financial Economics (September 1974), pp. 245-30́2.

Santoni, G. J. "The Effects of Inflation on Commercial Bank Stock Prices," this Review (forthcoming 1986).

Schwert, G. William. "The Adjustment of Stock Prices to Information About Inftation," Joumal of Finance (March 1981), pp. 15-29.

Sheehan, Richard G, "Weekly Money Announcements: New Intormation and lis Effects," this Review (August/September 1985), pp. $25-34$

Smillock, Michael, and Jess Yawitz. "Assef Retums, Discount Rate Changes, and Market Efficiency," Jounal of Finance (September 1985), pp. 114 $1-58$.

Sprinkel, Beryl W. Money and Stock Prices (Richard D. Irwir, Inc., 1964),

Sorensen, Eric H. "Rational Expectations and the Impact of Money upon Stock Prices," Joumal of Financial and Quantitative Analysis (December 1982), pp. 649-62.

Wallich, Henry C. "Recent Techniques of Monetary Policy," Federal Reserve Bank of Kansas City Economic Review (May 1984), pp. $21-30$.

\section{APPENDIX}

\section{Data Definitions}

\section{H. W}

The expected change in the money supply (EM) is the median forecast obtained from Money Market Services, Inc. (MMS).

Since 1977 this firm has conducted a weekly telephone survey of 50 to 60 government securities dealers to obtain their forecast of the change in M1. Before February 8,1980 , the survey was conducted wice each

week, inilially on Tuesday, with a follow-up call on Thursday, allowing respondents to alter their originat guess. From February 1980 through February 1984 , however, the survey was conducted only on Tuesday, because of the federal Reserve's shift in announcing the weekly M1 figures from Thursday to Friday afternoon. Beginning February 1984, which corresponds to the change from lagged to contemporaneous reserve accounting and with the amouncement day again being changed from Friday to Thursday afternoon, 
MMS once again used two surveys: the initial poll on the Friday immediately following the Thursday money announcoment and again on the following Tuesday. For this study, we use the forecasts from the Tuesday survey, The data used here are those from pearce and Roley (1985) as updated by Doug Pearce. We would like to thank him for making these as well as the actual $M 1$ data available.

Actual changes in weekly M1, which appear in the Federal Reserve's H.6 statistical release, are measured as the first announced value minus the first revised estimate of the previous week's level. Due to the changing definition of M1 during our sample, the following procednre was followed to obtain a series consistent with that being forecast by the survey respondents: Until February 1980, we use the old definition of M1. From February 1980 through November 1981, we use the actual M1B measure (not the M1B value that was "shift-adlusted" for the infoduction of NOW accountst. Finally, from November 1981 through the end of our sample, we use the curent definition of M1. Given the actual and expected series for money, unanticipated changes in M1 (UM) are measured as actual less expected.

\section{Chan Hownes}

The stock price indexes used in this study are daily close values of the broad Standard and Poor's (SP) 500 and 400 indexes, as well as the industry-specific indexes for transportation ISPTRAN), utilities (SPLIIL) and financial institutions (SPFIN). In each instance, the stock price change is measured as the difference of the logarithms.

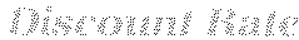

Changes in the lederal Reserve's discount rate and the surcharge are measured in percentage points; that is, a 100 basis point change in either rate is measured as 1.0. Our measurement of the discount rate change, unlike that in some studies, follows the Federal Re serve's official dating procedure, changing when one of the 12 Federal Reserve Banks has the approval of the Federal Resenve Board to change its rate. The data used here is based on the day the new rate is in effect not when the new rate is announced in the financial press. 